\title{
IN VITRO EVALUATION OF ANTIMICROBIAL AND ANTIBIOFILM ACTIVITY OF OLEUM HYPERICI: AN ORIGINAL PRODUCT FROM GOČ MOUNTAIN (SERBIA)
}

\author{
Mirjana Ž. Grujović ${ }^{* 1}$, Katarina G. Mladenović ${ }^{1}$, Ljiljana R. Čomić ${ }^{1}$ \\ and Aleksandar Glišović ${ }^{2}$ \\ ${ }^{1}$ University of Kragujevac, Faculty of Science, Department of Biology and Ecology, Radoja \\ Domanovića 12, 34000 Kragujevac, Republic of Serbia \\ ${ }^{2}$ „, Our paradise garden“, Kneza Mihajla 278, 34000 Kragujevac, \\ Republic of Serbia \\ *Corresponding author; E-mail: mirjana.grujovic@ @mf.kg.ac.rs
}

(Received December 9th, 2018; Accepted March 14th, 2019)

\begin{abstract}
This study observed the preliminary investigation of Oleum Hyperici, an original product made from Hypericum perforatum flowers, collected from Goč Mountain (Serbia). Some of the chemical properties ( $\mathrm{pH}$, the content of metals and metalloids - As, $\mathrm{Cr}, \mathrm{Pb}, \mathrm{Cd}, \mathrm{Ni}, \mathrm{Hg}$ ) and the microbiological safety of the product including the total count of aerobic mesophilic bacteria, coagulase positive staphylococci, Escherichia coli, Pseudomonas aeruginosa, Proteus sp., as well as fungi: molds and yeasts) were evaluated. Antimicrobial activity of $H$. perforatum oil against 18 species of bacteria was determined using the disc diffusion and microdilution methods, by determining the minimum inhibitory concentration (MIC) and the minimum bactericidal concentration (MBC). The antibiofilm activity of Oleum Hyperici was evaluated using the biofilm formation assay. The results indicated that oil did not contain potentially pathogenic microorganisms. Oleum Hyperici product showed the antimicrobial activity on the most of tested bacteria (inhibition zone was in a range from $14-24 \mathrm{~mm}$ ), except on Klebsiella pneumoniae ATCC 70063, K. pneumoniae, E. coli ATCC 25922, P. mirabilis, Bacillus subtilis ATCC 6633 and B. subtilis IP 5832. According to the obtained results, tested bacteria (planktonic and biofilm form) showed sensitivity up to $10^{-2}$ dilution of Oleum Hyperici. Based on the obtained preliminary results, it could be concluded that Oleum Hyperici can be used in traditional medicine for development control of some potential human pathogens.
\end{abstract}

Keywords: Oleum Hyperici, original product, food safety, biofilm, antimicrobial activity

\section{INTRODUCTION}

Hypericum perforatum (fam. Hypericaceae), also known as St John's wort, is wellknown medicinal herb, with its native habitat in Europe and Asia, but it can be found as invasive species in North America and Oceania (NG et al., 2017). It was used in folk medicine for treatment of burns, wounds, hematomas, inflammations and muscle pain (ISTIKOGLOU et al., 2010; MofFAT, 2014). An oil macerate of $H$. perforatum flowers (Oleum Hyperici) has been also widely used as a traditional medicine across Balkan countries for a long time, 
especially in Bosnia and Herzegovina and Serbia, mostly for healing skin ulcers, burns and wounds (SÜNTAR et al., 2010; ŠARIĆ-KUNDALIĆ et al., 2010; ŠAVIKIN et al., 2013) as an antiseptic, for liver and stomach complaints, as an antiphlogistic agent in the treatment of inflammation of the bronchi and urogenital tract, treatment of biliary disorders, bladder irritation, etc.

According to HPLC analysis, standardized extract of $H$. perforatum contains precisely $0.3 \%$ hypericin $(250 \mu \mathrm{g}$ per $300 \mathrm{mg})$ and twice as much pseudohypericin $(0.6 \%$ of the total extract) (BROCKMÖLLER et al., 1997). TIAN et al. (2014) indicated that $H$. perforatum contains hyperforin (phloroglucinol derivative currently thought to be the major psychoactive component of the plant) and adhyperforin. $H$. perforatum flowers contain many derivatives, including the flavonol hyperoside, biflavonols, xanthone derivatives, common phenolic acids (caddeic acid, chlorogenic acid, and ferulic acid), tannins and catechin derivative (DOSTALEK and STARK, 2012; MATEI et al. 2015).

The content of bioactive compounds in Oleum Hyperici, especially phenolic derivatives (thymol and carvacrol) depends of some factors, like geographical origin, ecological and agronomic condition and way of picking plants (SÜNTAR et al., 2010). It is well-known that many compounds showed sensitivity to light, humidity or heat, so the storage of plant is very important, too (BAKKALI et al., 2008, HYLDGAARD et al.,2012). SCHEMPP et al. (1999) and SADDIQE et al. (2010) indicated that hypericin and hyperforin have potential antibiotic properties, especially active against some Gram-positive bacteria. HEYDARIAN et al. (2017) indicated that polysaccharides from $H$. perforatum have good antimicrobial potential against some Gram-positive and Gram-negative bacteria. SÜNTAR et al. (2016) demonstrated that $H$. perforatum extracts showed good antagonistic potential against several oral bacteria. SARKISIAN et al. (2012) indicated that secondary metabolites from Hypericum spp. exhibit antibiofilm activities against Staphylococcus spp. SCHIAVONE et al. (2013) indicated that hyperforin had the ability to inhibit planktonic and biofilm cultures of $S$. aureus and $E$. faecalis.

The aim of this study was to examine some of the chemical properties of the Oleum Hyperici, as original, noncommercial product from Serbia, Goč Mountain and in vitro evaluation of microbiological safety of the products. Also, it is shown the possible impact on the planktonic growth and biofilm formation of selected bacteria, in order to evaluate the possible use of the product in commercial proposes.

\section{MATERIAL AND METHODS}

\section{Preparation of H. perforatum oil (Oleum Hyperici) original product}

The $H$. perforatum plants were collected on the Goč Mountain (1216 m altitude), during the 2017. It is located in central Serbia, in the Kopaonik mountain range. Eastern side of the mountain is covered with mixed forests (Fagus sp., Abies sp., Pinus nigra, Quercus petraea), while the west side is bare and rocky. An endemit of the Balkan, Acer heldreichii Orph. subsp. visianii (Nym.) K. Maly var. pancicii (K. Maly) Hayek), the variety of P. nigra (P. nigra var. gocensis Georgev) as well as 226 medicinal and aromatic plant species, which includes 25 taxa of endemic plants, can be found on Goč. The climate belongs to the type mountain variety of mild continental climate, with an average snow cover of $50 \mathrm{~cm}$. The highest peak of the mountain is Ljukten $(1216 \mathrm{~m})$. Goč has more than 250 springs with healthy drinking water and it is considered as a mountain of medical tourism, as it provides conditions for recovery of cardiovascular patients (GAJIĆ, 1984).

The plant material was collected before the sun zenith and after the sun rose (around 10 o'clock in the morning). Only flowers were used for the process of making the Oleum 
Hyperici (250 $\mathrm{g}$ of flowers was added into $1000 \mathrm{ml}$ of oil). After a 12-hour drying on natural wind, the flowers were macerated in the cold, unrefined olive oil (Olitalia, Olitalia SRI, Forli, Italy). The vessels in which we poured a mixture of olive oil and flowers were transparent, so the sun would be able to warm the mass more easily. These samples were set down at the sunniest point, so that the Sun shines most during the day following the procedure of the traditional practice in that region After 40 days, the vessels were drawn into the darkness and after twelve hours it was filtered through the gauze and the Oleum Hyperici, with familiar red color, was obtained.

\section{Determination of the sensory and chemical properties}

The sensory characteristics, as well as the $\mathrm{pH}$ and the content of metals and metalloids - As, $\mathrm{Cr}, \mathrm{Pb}, \mathrm{Cd}, \mathrm{Ni}, \mathrm{Hg}$ were performed according to standard approved methods for testing the food in the Food testing center, Belgrade, Serbia (https://www.cin.co.rs/) (POM-03-116; POM-03-AAS-03; POM-03-AAS-08; POM-03-AAS-09) (The Official Rules of the RS, No. 92/11).

\section{Microbiological safety}

Microbiological safety that included the total count of aerobic mesophilic bacteria, coagulase positive staphylococci, E. coli, P. aeruginosa, Proteus sp., molds and yeasts) of Oleum Hyperici was performed according to the accredited methods for testing the food in the Food testing center, Belgrade, Serbia (The Official Rules of the RS, No. 92/11).

\section{Microbial test strains}

The overnight cultures of the following 18 bacterial species were used: 8 isolates (Escherichia coli, Klebsiella pneumoniae, Salmonella typhimurium, Salmonella enterica, Proteus mirabilis, Pseudomonas aeruginosa, Enterococcus faecalis, Staphylococcus aureus) originated from human samples, 7 standard strains (E. coli ATCC 25923, K. pneumoniae ATCC 70063, P. mirabilis ATCC 12453, P. aeruginosa ATCC 27853, E. faecalis ATCC 29212, B. subtilis ATCC 6633, S. aureus ATCC 6538) and 3 probiotic strains (B. subtilis IP

5832, Lactobacillus plantarum, Bifidobacterium animalis subsp. lactis). All clinical isolates were a generous gift from the Institute of Public Health, Kragujevac, Serbia. The other microorganisms (ATCC strains and probiotics) were provided by the Microbiology Laboratory, Faculty of Science, University of Kragujevac, Serbia. The bacterial strains were kept in glycerol stock at $-80^{\circ} \mathrm{C}$ until use.

\section{The evaluation of antibacterial activity}

\section{Disk diffusion method}

The concentrated Oleum Hyperici, dissolved in Tween 20 (Fisher Scientific UK, Leicester, UK), was used for testing the antimicrobial activity. For screening of the antimicrobial activity, the disc diffusion method, with some modifications, was used (BAUER et al., 1966). Mueller-Hinton agar (Torlak, Belgrade, Serbia) was spilled into petri dishes and a solid disc of $8 \mathrm{~mm}$ diameter were made under sterile conditions. Then, the plates were inoculated with bacteria (suspension density $1.5 \times 10^{8} \mathrm{CFU} / \mathrm{ml}$ ), using a sterile swap. After the inoculation of the bacteria, $100 \mu \mathrm{l}$ of Oleum Hyperici was added into previously made disc, while $100 \mu \mathrm{l}$ of pure olive oil was used as negative control. The prepared samples were incubated for 24 hours at $37^{\circ} \mathrm{C}$. The results were interpreted by measuring the diameter of zone inhibition (the appearance of the inhibitory zone, in $\mathrm{mm}$ ). 


\section{Microdilution method}

The bacterial sensitivity on the Oleum Hyperici samples was expressed by determining the minimum inhibitory concentration (MIC) and minimum bactericidal concentration (MBC), using the microdilution method (SARKER et al., 2007). Two-fold serial dilutions of the oil, up to $10^{-7}$, were made in sterile 96-well microtiter plates containing $100 \mu \mathrm{l}$ of Mueller-Hinton broth (Torlak, Belgrade, Serbia) per well. From the overnight cultures of the tested strains of bacteria, the suspensions were prepared in a sterile $0.85 \%$ saline solution. For the standardization of bacterial suspensions, the Mc Farland standard number 0.5 was used (bacteria density of $1.5 \times 10^{8} \mathrm{CFU} / \mathrm{ml}$ ), and the samples were diluted until the density was $5 \times 10^{5} \mathrm{CFU} / \mathrm{ml}$. In each well, it was added $10 \mu \mathrm{l}$ of the suspension of the tested bacteria. The microtiter plates were incubated at $37^{\circ} \mathrm{C}$ for 24 hours. Resazurin (Alfa Aesar GmbH \& Co., Karlsruhe, Germany), an indicator of cell growth, was added, in order to read the results of the inhibitory effect of the Oleum Hyperici on the growth of bacteria. The extensive reduction of resazurin by metabolically active cells would lead to the color change of the blue-purple in pink, which indicates the emergence of growth and thus an underestimation of cellular activity (O'BRIEN et al., 2000). The lowest concentration at which there was no change in the color of the indicator was determined as the minimum inhibitory concentration.

MBCs were determined by screening samples from the wells of the microtiter plates in which no growth was observed after 24 hours on a solid nutrient agar (Torlak, Belgrade, Serbia). After incubation, the lowest concentration at which growth was not observed (without colonies), was considered to be the minimum bactericidal concentration. Each experiment contains growth control, sterility control and positive control (standard antibiotic ampicillin and tetracycline (Sigma Chemicals Co., USA), dissolved in nutrient liquid medium). Each test was done in duplicate and the results are shown as the mean value.

\section{Antibiofilm activity of Oleum Hypericum}

The experiment was performed according to the method described by O'TOOLE and KOLTER (1998). In order to determine the influence of Oleum Hyperici on bacteria which are causers of skin infections, the following bacterial strains were used: S. aureus, S. aureus ATCC 6538, P. aeruginosa and $P$. aeruginosa ATCC 9027. The 96-well microtiter plates (Sarstedt, Nümbrecht, Germany) were used, and in each well (except the first row), a $100 \mu 1$ of Mueller-Hinton broth was added. A $200 \mu \mathrm{l}$ of the pure Oleum Hyperici was added to the first row of wells, and twofold serial dilutions were made, up to $10^{-7}$. Then $10 \mu \mathrm{l}$ of bacterial suspension (0.5 McFarland for Gram-negative and $1 \mathrm{McF}$ arland for Gram-positive bacteria) was added to each well. The inoculated microtiter plates were incubated at $37^{\circ} \mathrm{C}$ for 48 hours (time in which biofilm can be formed). The rest of the experiment was performed according to the modified method described in detail in MURUZOVIĆ et al. (2016).

Only broth or broth with Oleum Hyperici served as control to check sterility and nonspecific binding of media. To compensate for background absorbance, OD readings from sterile medium, olive oil, fixative, and dye were averaged and subtracted from all test values. All tests were performed in duplicate and determined with (ELISA) plate reader (T-2100C, Rayto, Shenzhen, China) at $630 \mathrm{~nm}$ wavelength.

\section{RESULTS AND DISCUSSION}

\section{Sensory, chemical and microbiological properties}

The oil tested presents the extract made from flowers of autochthonous plant $H$. perforatum, extracted in the commercial olive oil. Based on the examinations of sensory 
characteristics, it was concluded that this is the red, oil liquid with moderately intense scent, which resembles on the olive oil smell. The results of the chemical characteristics of the Oleum Hyperici are presented in Table 1. Based on the results, it could be concluded that the content of metals and metalloids are in accordance with the standards for food samples.

Table 1. The chemical characteristics of the Oleum Hyperici

\begin{tabular}{ccc}
\hline Parameters & Results & Used method \\
\hline pH & 7.0 & POM-03-116 \\
\hline \multicolumn{2}{c}{ The content of metals and metalloids ${ }^{1}$} \\
\hline As & $<0.1$ & POM-03-AAS-09 \\
$\mathbf{C r}$ & $<5$ & POM-03-AAS-03 \\
$\mathbf{P b}$ & $<5$ & POM-03-AAS-03 \\
$\mathbf{C d}$ & $<0.5$ & POM-03-AAS-03 \\
$\mathbf{N i}$ & $<5$ & POM-03-AAS-03 \\
Hg & $<0.1$ & POM-03-AAS-08 \\
\hline${ }^{1}$ Values are given in $\mathrm{mg} / \mathrm{kg}$ &
\end{tabular}

The results of microbiological testing were presented in Table 2. Based on the results, it could be concluded that the oil is safe for using because it does not contain potential pathogenic microorganisms according to the standards for food samples (The Official Rules of the RS, No. 92/11).

Table 2. Microbiological safety of Oleum Hyperici

\begin{tabular}{|c|c|c|}
\hline Parameters & Results & Used method \\
\hline Total count of aerobic mesophilic bacteria $(\mathrm{CFU} / \mathrm{g}(\mathrm{ml}))$ & $<10$ & G II/1 \\
\hline Coagulase positive staphylococci $\left(0.1 \mathrm{~g}(\mathrm{ml})\right.$ at $37^{\circ} \mathrm{C}$ & n.d & GI II/2 \\
\hline E. coli $0.1 \mathrm{~g}(\mathrm{ml})$ & n.d & $\mathrm{II} / 4$ \\
\hline P. aeruginosa $0.1 \mathrm{~g}(\mathrm{ml})$ & n.d & $\mathrm{II} / 3$ \\
\hline Proteus sp. $0.1 \mathrm{~g}(\mathrm{ml})$ & n.d & $\mathrm{II} / 5$ \\
\hline Total count of Molds and yeasts $(\mathrm{CFU} / \mathrm{g}(\mathrm{ml}))$ & $<10$ & II/1 \\
\hline
\end{tabular}

n.d-not detected in the sample

\section{Antibacterial activity of Oleum Hyperici}

The antibacterial activity of the Oleum Hyperici, as the original product from Serbia, for the first time, was investigated in this study, using the two methods: disk diffusion and microdilution method.

According to the results obtained from disk diffusion method (Table 3), the most of tested bacteria (12 strains) showed sensitivity to the Oleum Hyperici reaching the inhibition zone in a range from $14-24 \mathrm{~mm}$, but the zones were turbid. None of activity was obtained against $K$. pneumoniae ATCC 70063, K. pneumoniae, E. coli ATCC 25922, P. mirabilis and B. subtilis ATCC 6633. Pure olive oil did not show the impact on the bacterial growth. The results of the sensitivity of tested bacteria to antibiotics were showed in Table 4.

According to the results from microdilution method, tested bacterial strains showed sensitivity only to the first and second dilution of Oleum Hyperici, while MBC was only detected in undiluted (pure) Oleum Hyperici (Table 4). 
Table 3. Antimicrobial activity of the Oleum Hyperici (disc diffusion method)

\begin{tabular}{|c|c|c|}
\hline \multirow[t]{2}{*}{ Species } & \multicolumn{2}{|c|}{ Oleum Hyperici } \\
\hline & $\mathbf{Z I}^{1}$ & $\mathbf{Z A}^{2}$ \\
\hline K. pneumoniae ATCC70063 & I & I \\
\hline K. pneumoniae & l & l \\
\hline E. coli & 18 & $\mathrm{~T}$ \\
\hline E. coli ATCC 25922 & / & l \\
\hline P. aeruginosa & 24 & $\mathrm{~T}$ \\
\hline P. aeruginosa ATCC 27853 & 20 & $\mathrm{~T}$ \\
\hline P. mirabilis & / & / \\
\hline P. mirabilis ATCC 12543 & 20 & $\mathrm{~T}$ \\
\hline S. typhimurium & 16 & $\mathrm{~T}$ \\
\hline S. enterica & 18 & $\mathrm{~T}$ \\
\hline E. faecalis & 16 & $\mathrm{~T}$ \\
\hline E. faecalis ATCC 39212 & 16 & $\mathrm{~T}$ \\
\hline S. aureus & 20 & $\mathrm{~T}$ \\
\hline S. aureus ATCC 25923 & 22 & $\mathrm{~T}$ \\
\hline B. subtilis ATCC 6633 & / & / \\
\hline L. plantarum & 14 & $\mathrm{~T}$ \\
\hline B. animalis subsp. Lactis & 16 & $\mathrm{~T}$ \\
\hline B. subtilis IP 5832 & l & l \\
\hline
\end{tabular}

${ }^{1}$ Zone of inhibition (mm);

${ }^{2}$ Zone appearance $(\mathrm{C}$ - clear zone of inhibition;

$\mathrm{T}$ - turbid zone of inhibition; / - none zone of inhibition)

Table 4. Antimicrobial activity of the Oleum Hyperici (microdilution method)

\begin{tabular}{lcccccc}
\hline \multicolumn{1}{c}{ Species } & \multicolumn{2}{c}{ Oleum } & \multicolumn{2}{c}{ Ampicillin } & \multicolumn{2}{c}{ Tetracycline } \\
\cline { 2 - 7 } & MIC & MBC & MIC & MBC & MIC & MBC \\
\hline K. pneumoniae ATCC 70063 & $10^{-1}$ & $\mathrm{p}$ & $\mathrm{n} . \mathrm{d}$ & $\mathrm{n} . \mathrm{d}$ & $\mathrm{n} . \mathrm{d}$ & $\mathrm{n} . \mathrm{d}$ \\
K. pneumoniae & $10^{-1}$ & $\mathrm{p}$ & $>128$ & $>128$ & 4 & 32 \\
E. coli & $10^{-1}$ & $\mathrm{p}$ & 2.1 & 1.2 & 2 & 6 \\
E. coli ATCC 25922 & $10^{-1}$ & $\mathrm{p}$ & 0.37 & 0.5 & 4 & 6 \\
P. aeruginosa & $10^{-2}$ & $\mathrm{p}$ & $>128$ & $>128$ & $>128$ & $>128$ \\
P. aeruginosa ATCC 27853 & $10^{-2}$ & $\mathrm{p}$ & $>128$ & $>128$ & 4 & 32 \\
P. mirabilis & $10^{-1}$ & $\mathrm{p}$ & $>128$ & $>128$ & $>128$ & $>128$ \\
P. mirabilis ATCC 12543 & $10^{-1}$ & $\mathrm{p}$ & $\mathrm{n} . \mathrm{d}$ & $\mathrm{n} . \mathrm{d}$ & $\mathrm{n} . \mathrm{d}$ & $\mathrm{n} . \mathrm{d}$ \\
S. typhimurium & $10^{-1}$ & $\mathrm{p}$ & 2 & 2 & 2 & 2 \\
S. enterica & $10^{-1}$ & $\mathrm{p}$ & 1 & 1 & 2 & 4 \\
E. faecalis & $10^{-2}$ & $\mathrm{p}$ & 4 & 6 & 1 & 6 \\
E. faecalis ATCC 39212 & $10^{-1}$ & $\mathrm{p}$ & 0.25 & 0.75 & 1.5 & 3 \\
S. aureus & $10^{-2}$ & $\mathrm{p}$ & $<0.06$ & $<0.06$ & $<0.06$ & $<0.06$ \\
S. aureus ATCC 25923 & $10^{-2}$ & $\mathrm{p}$ & 0.25 & 0.75 & 1.5 & 3 \\
B. subtilis ATCC 6633 & $10^{-1}$ & $\mathrm{p}$ & 3 & 4 & 0.25 & 0.37 \\
L. plantarum & $10^{-1}$ & $\mathrm{p}$ & $\mathrm{n} . \mathrm{d}$ & $\mathrm{n} . \mathrm{d}$ & $\mathrm{n} . \mathrm{d}$ & $\mathrm{n} . \mathrm{d}$ \\
B. animalis subsp. Lactis & $10^{-1}$ & $\mathrm{p}$ & $<0.06$ & 0.12 & 4 & 8 \\
B. subtilis IP 5832 & $10^{-1}$ & $\mathrm{p}$ & 8 & 16 & $<0.06$ & $<0.06$ \\
\hline
\end{tabular}

Minimum inhibitory concentration (MIC) and minimum bactericidal concentration (MBC) values given in dilutions of $H$. perforatum oil (p-pure $H$. perforatum oil) and for antibiotics as $\mu \mathrm{g} / \mathrm{ml}$; n.dnot determined 
Due to the more often appearance of antibiotic resistant bacteria, there is a need for development of natural protection from bacterial infections. According to the KALABA et al. (2015), S. aureus, S. typhimurium and $P$. aeruginosa are the most common pathogenic bacteria that cause health and economic problems. Oleum Hyperici tested in this study, demonstrated the influence on the mentioned bacteria. HEYDARIAN et al. (2017) indicated that polysaccharides from $H$. perforatum have a good antimicrobial potential against $E$. coli, $S$. typhi, B. cereus and $S$. aureus, according to the disk-diffusion method, which was confirmed in our study. SÜNTAR et al. (2016) demonstrated that $H$. perforatum extracts showed antimicrobial potential against Streptococcus mutans, S. sobrinus, Lactobacillus plantarum and Enterococcus faecalis (oral bacteria). MARČETIĆ et al. (2016) indicated that hyperforin and hypericin are responsible for antibacterial activity of $H$. perforatum against $B$. subtilis, E. faecalis, Staphylococcus epidermidis and Micrococcus luteus. GIBBONS et al. (2002) indicated the activity of oil against Gram-negative bacteria. The results from our study showed that tested Oleum Hyperici, made from flowers of $H$. perforatum from Goč Mountain, had a good antimicrobial potential although detection of compounds should be done in further studies.

\section{Antibiofilm activity}

The antibiofilm activity of the Oleum Hyperici was determined using the biofilm formation assay (O'TOOLE and KOLTER (1998). Four strains of tested bacteria (S. aureus, $S$. aureus ATCC 25923, P. aeruginosa and P. aeruginosa ATCC 27853) were chosen because they are a well-known causative agents of skin infections. The results are presented in Table 5 .

The results indicated that tested bacteria showed no ability of biofilm formation in first and second dilution. Up to dilution $10^{-5}$, among tested bacteria, only $S$. aureus clinical isolate showed the ability of significant biofilm formation (78\%, compared to growth control).

Table 5. Antibiofilm activity of Oleum Hyperici

\begin{tabular}{ccccc}
\hline $\begin{array}{c}\text { Dilutions of } \\
\text { Oleum Hyperici }\end{array}$ & S. aureus & $\begin{array}{c}\text { S. aureus } \\
\text { ATCC 25923 }\end{array}$ & P.aeruginosa & $\begin{array}{c}\text { P. aeruginosa } \\
\text { ATCC 27853 }\end{array}$ \\
\hline $10^{-1}$ & $/$ & $/$ & $/$ & $/$ \\
$10^{-2}$ & $/$ & $/$ & $/$ & $/$ \\
$10^{-3}$ & 50 & 28.6 & 7.8 & 33.3 \\
$10^{-4}$ & 75 & 35.7 & 15.7 & 38.9 \\
$10^{-5}$ & 78 & 50 & 35.3 & 55.6 \\
\hline
\end{tabular}

The results are presented as percent of growth of biofilm in different dilutions of $\mathrm{H}$. perforatum oil, compared with growth control of biofilm (100\%); /- no biofilm formed

Antibiofilm activity of Oleum Hyperici was investigated in a few studies, but the tested original product from Serbia was not investigated so far. SARKISIAN et al. (2012) and SCHIAVONE et al. (2013) indicated that secondary metabolites from Hypericum spp. had antibiofilm activity against $S$. aureus, S. epidermidis and E. faecalis. In our study, tested Oleum Hyperici showed antibiofilm activity on all four tested bacteria in first and second dilution. The results of antibiofilm activity were better than results of $\mathrm{MBC}$, which was only detected in pure Oleum Hyperici. This suggests that the traditional Oleum Hyperici formulation, originated plant from specific area (Goč Mountain) may have utility in regulation of bacterial virulence and pathogenesis that are involved in skin infections. 


\section{CONCLUSION}

H. perforatum oil, Oleum Hyperici, has a positive effect on human health and inhibition of the growth of bacteria. The oil can be used as additional supplement for preventing or a treatment of infections caused by pathogenic microorganisms. The oil tested in this study presents the original product, made from $H$. perforatum flowers, collected from the specific area of Goč Mountain, and olive oil from Italy. Based to the results of this study, it could be concluded that this original product is safe for human use with an influence on the bacteria tested in this study, in vitro. Also, the influence on the biofilm formation on some potential skin pathogens, was significant. The results presented in this paper indicate that this folk medical therapy for skin and some tissue infections could represent a safe and efficient therapy.

\section{Acknowledgments}

This investigation was supported by the Ministry of Education, Science and Technological Development of the Republic of Serbia (Grant No. 41010).

\section{References:}

[1] Bakkali, F., Averbeck, S., Averbeck, D., Idaomar, M. (2008): Biological effects of essential oils - a review. Food and Chemical Toxicoogy 46: 446-475. doi: 10.1016/j.fct.2007.09.106

[2] BAuer, A.W., Kirby, W.M.M., Serris, J.C., TurCK, M. (1966): Antibiotic susceptibility testing by a standardized single disc method. American Journal of Clinical Pathology 45: 493-496.

[3] Brockmöller, J., Reum, T., Bauer,S., Kerb, R., HÜBner, W.D., Roots, I. (1997): Hypericin and pseudohypericin: pharmacokinetics and effects on photosensitivity in humans. Pharmacopsychiatry 30: 94-101.

[4] DostaleK, M., Stark, A.K. (2012): St. John's Wort (Hypericum perforatum L.). In: Anzenbacher, P., Zanger, U.M. (ed) Metabolism of drugs and other xenobiotics. Weinheim: Wiley-VCH Verlag GmbH \& Co. KGaA, p. 583-610.

[5] GAJIĆ, M.R. (1984): Flora Goca-Gvozdac. University of Belgrade, Faculty of Forestry (in Serbian)

[6] Gibbons, S., Ohlendorf, B., Johnsen, I. (2002): The genus Hypericum - a valuable resource ofanti-Staphylococcal leads. Fitoterapia 73: 300-304. doi: 10. 1016/S0367-326X(02)00082-5

[7] Heydarian, M., JoOyAndeh, H., NASEHI, B., Noshad, M. (2017): Characterization of Hypericum perforatum polysaccharides with antioxidant and antimicrobial activities: optimization based statistical modeling. International Journal of Biological Macromolecul 104: 287-293. doi: 10.1016/j.ijbiomac.2017. 06.049

[8] Hyldgandd, M., Mygind, T., Meyer, R.L. (2012): Essential oils in food preservation: mode of action, synergies, and interactions with food matrix components. Frontiers in Microbiology 3: 12. doi: 10.3389/fmicb.2012.00012.

[9] Istikoglou, C.I., Mavreas, V., Geroulanos, G. (2010): History and therapeutic properties of Hypericum perforatum from antiquity until today. Psychiatriki 21: 332 338. 
[10] Kalaba, V., Glušac, J., Stijepić, M., Kalaba, D., ĐurĐević MiloseviČ, D. (2015): Antimicrobial activity of Hypericum perforatum essential oil. Quality of life 6: 45-52. doi: 10.7251/QOL1503045K

[11] Marčetić, M.D., Milenković, M.T, LAKuŠIĆ, D.V., LAKuŠIĆ,B.S. (2016): Chemical composition and antimicrobial activity of the essential oil and methanol extract of Hypericum aegypticum subsp. webbii (Spach) N. Robson. Chemistry and Biodiversity 13: 427-436. doi: 10.1002/cbdv.201500119

[12] MateI, A.O., Gatea, F., RAdU, G.L. (2015): Analysis of phenolic compounds in some medicinal herbs by LC-MS. Journal of Chromatographic Science 53: 1147-1154. doi: 10.1093/chromsci/bmu177

[13] Moffat, B. (2014): Archaeological sources for the history of herbal medicine practice: The case study of St John's wort with valerian at Soutra medieval hospital. In: Francia, S.,Stobart, A.(ed). Critical ppproaches to the history of Western herbal medicine: From classical antiquity to the early modern period. Bloomsbury London, UK, p. 253-270.

[14] Muruzović, M.Ž., Mladenović, K.G., Stefanović, O.D., Vasić, S.M., ČOMić, L.R. (2016): Extracts of Agrimonia eupatoria L. as sources of biologically active compounds and evaluation of their antioxidant, antimicrobial, and antibiofilm activities. Journal of Food and Drug Analysis 24: 539-547. doi: 10.1016/j.jfda. 2016.02.007

[15] NG, Q.X., Venkatanarayanan, N., Ho, C.Y.X. (2017): Clinical use of Hypericum perforatum (St John's wort) in depression: a meta-analysis. Journal of Affective Disorders 210: 211-221. doi: 10.1016/j.jad.2016.12.048

[16] O'Brien, J., Wilson, I., Orton, T., PognAN, F. (2000): Investigation of the Alamar Blue (resazurin) fluorescent dye for the assessment of mammalian cell cytotoxicity. European Journal of Biochemistry 267(17): 5421-5426.

[17] O'Toole, G., Kolter, R. (1998): Initiation of biofilm formation in Pseudomonas fluorescens WCS365 proceeds via multiple, convergent signalling pathways: a genetic analysis. Molecular Microbiology 28: 449-461. doi:10.1046/j.1365-2958. 1998.00797.x

[18] SAdDiQe, Z., NAeEm, I., Maimoona, A. (2010): A review of the antibacterial activity of Hypericum perforatum L. Journal of Ethnopharmacology 131: 511-521. doi: 10.1016/j.jep.2010.07.034

[19] ŠARIĆ-KundAlić, B., FrITZ, E., DoBEŠ, C., SAUKEL, J. (2010): Traditional medicine in the Pristine village of Prokoškolake on Vranica Mountain, Bosnia and Herzegovina. Scientia Pharmaceutica 78:275-290. doi:10.3797/scipharm.1003-06

[20] SARKer, S.D., NAhar, L., Kumarasamy, Y. (2007): Microtitre plate-based antibacterial assay incorporating resazurin as an indicator of cell growth, and its application in the in vitro antibacterial screening of phytochemicals. Methods 42: 321324. doi: 10.1016/j.ymeth.2007.01.006

[21] Sarkisian, S.A., Janssen, M.J., Matta, H., Henry, G.E., LaPlante, K.L., Rowley, D.C. (2012): Inhibition of bacterial growth and biofilm production by constituents from Hypericum spp. Phytotherapy Research 6: 1012-1016. doi: 10. 1002/ptr.3675

[22] Šavikin, K., Zdunić,G., Menković, N., Žıvković, J., Ćujić, N., Tereščenko, M.,BIGOVIĆ. D. (2013): Ethnobotanical study on traditional use of medicinal plants in South-Western Serbia, Zlatibor district. Journal of Ethnopharmacology 146: 803-810. doi: 10.1016/j.jep.2013.02.006 
[23] Schempr, C.M., Klaus, P., WitTmer, A., SchöPf, E., Simon, J.C. (1999): Antibacterial activity of hyperforin from St John's wort, against multiresistant Staphylococcus aureus and gram-positive bacteria. The Lancet 353: 2129. doi:10.1016/S0140-6736(99)00214-7

[24] Schiavone, B.I.P., Rosato, A., Marilena, M., Gibbons, S., Bombardelli, E., VerotTA, L., Franchini, C., CoRbO, F. (2013): Biological evaluation of hyperforin and its hydrogenated analogue on bacterial growth and biofilm production. Journal of Natural Products 76: 1819-1823. doi: 10.1021/np400394c

[25] SÜNTAR, I.P., AKKOL, E.K., YILMAZER, D., BAYKAL, T.K., IRMIZIBEKMEZ, H., AlPER, M., YeşiladA, E. (2010): Investigation on the in vivo wound healing potential of Hypericum perforatum L. Journal of Ethnopharmacology 127: 468-477. doi: 10.1016/j.jep.2009.10.011

[26] SÜNTAR, I., OYARDi, O., AKKol, E.K., OzceliK, B. (2016): Antimicrobial effect of the extracts from Hypericum perforatum against oral bacteria and biofilm formation. Pharmaceutical Biology 54: 1065-1070. doi: 10.3109/13880209.2015. 1102948

[27] THE OfFICIAL RULES OF THE RS, No. 92/11 (http://www.pks.rs/SADRZAJ/Files/ Zakon\%20o\%20zdravstvenoj\%20ispravnosti.pdf)

[28] Tian, J., Zhang, F., Cheng, J., Guo, S., Liu, P., Wangb, H. (2014): Antidepressantlike activity of adhyperforin, a novel constituent of Hypericum perforatum L. Scientific Reports 4: 5632. doi: 10.1038/srep05632 